\title{
Altitudinal changes of surface pollen and vegetation on the north slope of the Middle Tianshan Mountains, China
}

\author{
YANG Zhenjing ${ }^{1,2 *}$, ZHANG Yun ${ }^{2}$, REN Haibao ${ }^{2}$, YAN Shun ${ }^{3}$, KONG Zhaochen ${ }^{2}$, MA \\ Keping $^{2}$, NI Jian ${ }^{4}$ \\ ${ }^{1}$ Institute of Hydrogeology and Environmental Geology, Chinese Academy of Geological Sciences, Shijiazhuang 050061, \\ China; \\ ${ }^{2}$ State Key Laboratory of Vegetation and Environmental Change, Institute of Botany, Chinese Academy of Sciences, Beijing \\ 100093, China; \\ ${ }^{3}$ Xinjiang Institute of Ecology and Geography, Chinese Academy of Sciences, Urumqi 830011, China; \\ ${ }^{4}$ State Key Laboratory of Environmental Geochemistry, Institute of Geochemistry, Chinese Academy of Sciences, Guiyang \\ 550002 , China
}

\begin{abstract}
To provide information on vegetation patterns and altitudinal distributions of pollen assemblage in surface soil layers, their complicated relationships in a dryland mountain-basin system in northwestern China and a realistic basis for paleovegetational reconstruction, we investigated 86 vegetation quadrats and analyzed 80 soil samples from the surface soil layers along an altitudinal transect on the north slope of the Middle Tianshan Mountains from alpine cushion vegetation at 3,510 m near glacier to desert vegetation at $460 \mathrm{~m}$ in the Gurbantunggut Desert. According to surface pollen assemblages and the results of the detrended correspondence analysis, the transect can be divided into six major altitudinal pollen zones as alpine cushion vegetation, alpine and subalpine meadows, montane Picea forest, forest-steppe ecotone, Artemisia desert and typical desert, which basically reflect the characteristics of the mountainous vegetation patterns on the north slope of the Middle Tianshan Mountains. However, Picea pollen also exists outside the spruce forest, Chenopodiaceae and Artemisia pollen appeared above the elevation of 1,300 $\mathrm{m}$, indicating that most of them might be introduced from lower elevations by upslope winds. Airborne pollen researches from three regions at different elevations further suggest that a high-frequency northwest anabatic wind has a remarkable influence on the transportation and dispersion of surface pollen in the area.
\end{abstract}

Keywords: altitudinal transect; vegetation zone; pollen assemblage; Picea forest; the Middle Tianshan Mountains

Citation: YANG Zhenjing, ZHANG Yun, REN Haibao, YAN Shun, KONG Zhaochen, MA Keping, NI Jian. 2016. Altitudinal changes of surface pollen and vegetation on the north slope of the Middle Tianshan Mountains, China. Journal of Arid Land, 8(5): 799-810. doi: 10.1007/s40333-016-0085-9

The relationship between pollen assemblage in surface soil layers and vegetation types can be used to understand the complicated interaction between fossil pollen spectra and past vegetation composition, and to infer past climate changes (Xu et al., 2009; Zhang et al., 2010; Li et al., 2012; Zhang et al., 2015). Pollen archives convey accurate environmental information, such as temperature, precipitation and human disturbances (Herzschuh et al., 2010). Many factors including pollen production, dispersal, deposition and preservation affect surface pollen

*Corresponding author: YANG Zhenjing (E-mail: yangzhenjing1966@163.com)

Received 2015-08-10; revised 2016-03-23; accepted 2016-04-07

(C) Xinjiang Institute of Ecology and Geography, Chinese Academy of Sciences, Science Press and Springer-Verlag Berlin Heidelberg 2016 
assemblage, which make pollen-vegetation-climate research comparatively complicated (Dai et al., 2011). The complicated interaction between surface pollen and modern vegetation should be widely investigated in different geographical regions to provide reliable results and valuable information for past climate reconstruction and further researches.

Mountain is a typical area for studying the modern pollen-vegetation relationship due to its specific topography and pollen dispersal air transport mechanism (Markgraf, 1980; Solomon and Silkworth, 1986; Fall, 1992a, b; Davies and Fall, 2001; Lu et al., 2011). In mountainous areas, modern pollen rains can be distinguished by their main vegetation zones at different elevations (e.g. Davies and Fall, 2001; Yu et al., 2001), which could provide a measure for the reliability of using fossil pollen spectra to reconstruct past vegetation patterns. For the mountains located in the arid areas with vegetation types from lowland deserts and steppes to mountainous forests and alpine meadows, the pollen-vegetation relationship is particularly important (Solomon and Silkworth, 1986; Fall, 1992a; Davies and Fall, 2001).

In Xinjiang, a number of studies were conducted on modern pollen assemblage and its relationship with vegetations in the past two decades (Yan and $\mathrm{Xu}, 1989$; Pan, 1993; Yan, 1993; $\mathrm{Xu}$ et al., 1996; Yan et al., 2004; Luo et al., 2009). However, descriptive or quasi-quantitative studies could not reflect the quantitative relationship between pollen assemblage in surface soil layer and vegetation, especially in the regions around the Middle Tianshan Mountains where have various vegetation types and unique topographies. Therefore, the objective of this study was to explore the complicated relationship between pollen spectra characteristics and modern vegetation using statistical analysis. These results might contribute to the quantitative reconstruction of past vegetation and climate changes in Xinjiang.

\section{Materials and methods}

\subsection{Study area}

The study area is located on the north slope of the Middle Tianshan Mountains in Xinjiang (Fig. 1), where the vegetation displays a vertical distribution from 3,900 $\mathrm{m}$ at alpine cushion vegetation to $400 \mathrm{~m}$ in the Gurbantunggut Desert with a horizontal distance about $80 \mathrm{~km}$ from the south to the north. Glacier and perennial snow cover a large area at above 3,900 m. Vertical vegetation belts span elevations below 3,900 $\mathrm{m}$ with alpine cushion vegetation at 3,900-3,400 m, alpine and sub-alpine meadow at 3,400-2,600 m, Tianshan spruce (Picea schrenkiana) forest at 2,600-1,720 $\mathrm{m}$, forest-steppe ecotone at 1,720-1,300 m, Artemisia desert at 1,300-700 m and typical desert at below $700 \mathrm{~m}$ (Fig. 2; Comprehensive Investigation Team of Xinjiang and Institute of Botany, Chinese Academy of Sciences, 1978; Editorial Committee for Forests of Xinjiang, 1989).

\subsection{Pollen sampling and vegetation survey}

In the summer of 2002, a transect was set up on the north slope of the Middle Tianshan Mountains along an altitudinal gradient from 3,510 to $460 \mathrm{~m}$ (Fig. 1) to collect pollen in surface soil layers and to investigate modern vegetation. The transect started at $43^{\circ} 47^{\prime} 34^{\prime \prime} \mathrm{N}, 88^{\circ} 13^{\prime} 26^{\prime \prime} \mathrm{E}$ and ended at $43^{\circ} 23^{\prime} 56^{\prime \prime} \mathrm{N}, 88^{\circ} 54^{\prime} 17^{\prime \prime} \mathrm{E}$. Total 86 vegetation quadrats, $20 \mathrm{~m} \times 20 \mathrm{~m}$ each, were investigated along the transect (Table 1) with two or three quadrats in each vegetation zone at an elevational interval of 20-100 m. Tree, shrub and herb were investigated if existed in quadrats. In each quadrat, the number of trees, tree species, height, canopy range and diameter at breast height were recorded. Each quadrat was divided into four plots, $10 \mathrm{~m} \times 10 \mathrm{~m}$ each. Shrub species, the number of shrubs, height and canopy range were counted in each plot. Two subplots, $1 \mathrm{~m} \times 1 \mathrm{~m}$ each, were randomly selected in each plot and herb species, height and coverage were recorded. At the same time, moss polsters (forest only), litter and topsoil (forest and grassland) were taken randomly at each vegetation quadrat and then mixed and sealed into a plastic box as an one-site sample. In total, 80 surface soil samples were collected by this cinquefoil sampling method (Table 1).

\subsection{Pollen extracting and counting}

We used $50 \mathrm{~g}$ soil from each sample for pollen analysis. Pollen was extracted from the soil using 


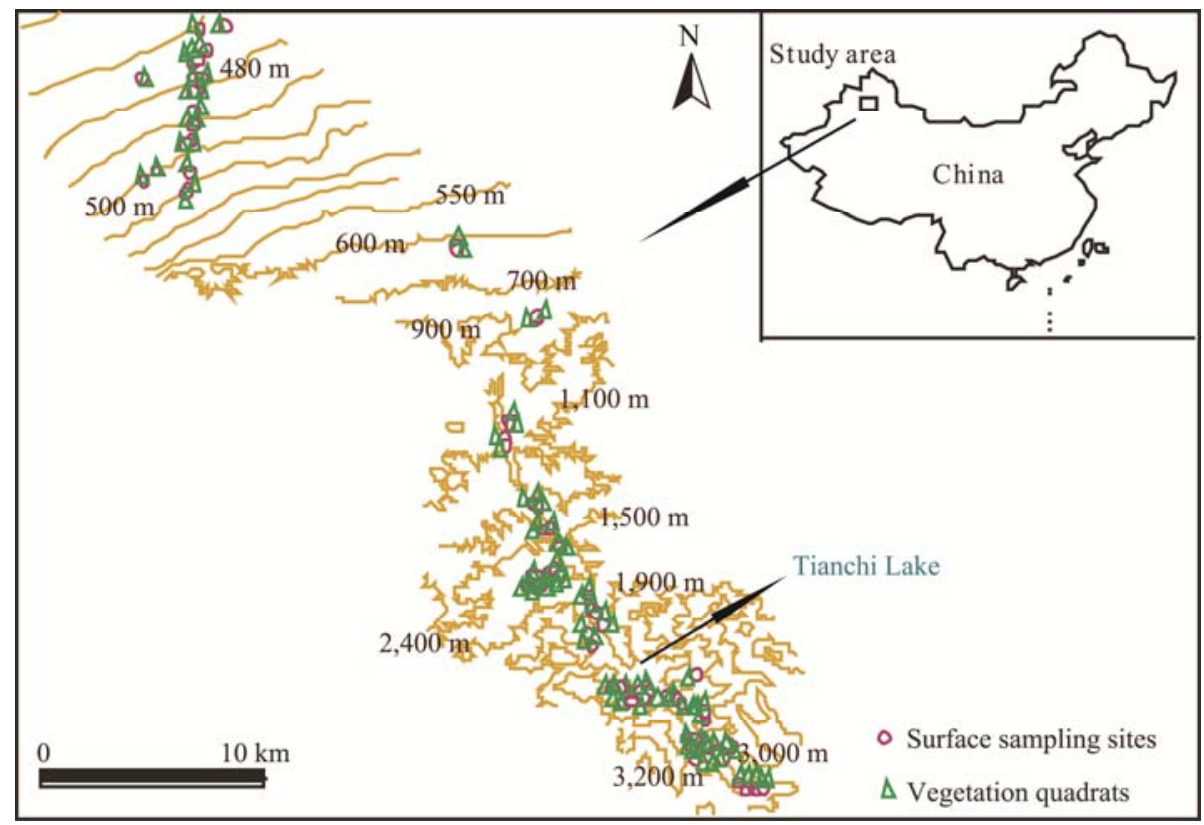

Fig. 1 Sampling locations along an altitudinal gradient on the north slope of the Middle Tianshan Mountains

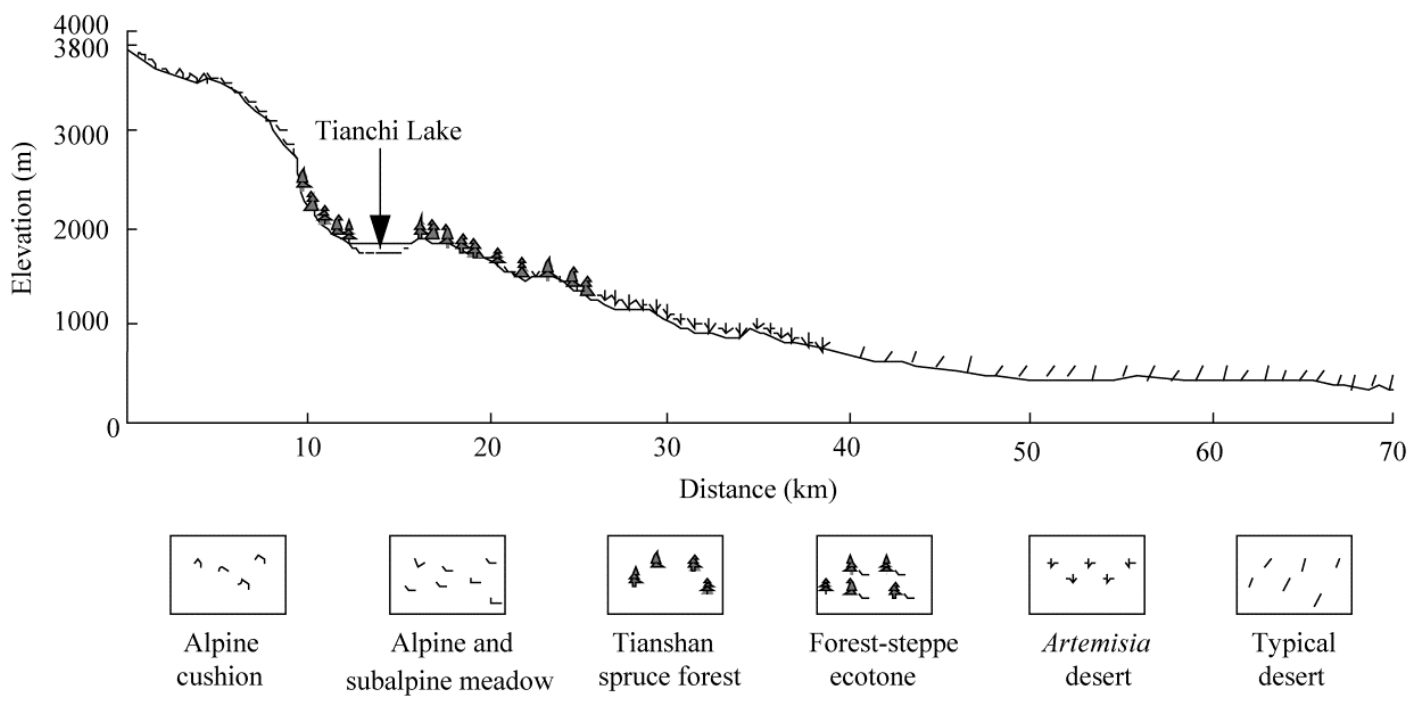

Fig. 2 Vegetation vertical distribution on the north slope of the Middle Tianshan Mountains

classic treatments of $\mathrm{K}_{2} \mathrm{CO}_{3}, \mathrm{HCl}, \mathrm{HF}$, concentrated $\mathrm{HCl}$, heavy liquid and acetolysis mixture ( $\mathrm{Li}$ et al., 1995). Treated pollen samples were placed in glycerin and examined with the Olympus microscope. Two or three slices were examined for each sample and at least 300 terrestrial pollen grains (mean, 406) were counted. Pollen identification was based on information from published books of palynology and pollen morphology (Xi and Ning, 1994; Wang et al., 1995). Unknown and indeterminate pollen grains such as broken, concealed, corroded, crumpled and degraded ones were excluded. We identified 56 pollen families and genera.

\subsection{Data analysis}

Pollen taxa with percentage composition up to $0.5 \%$ were chosen for data analysis. About 17 taxa were used for detrended correspondence analysis (DCA) (ter Braak et al., 2002 ), including Picea, Betula, Salix, Ephedra, Tamarix, Nitraria, Chenopodiaceae, Compositae, Artemisia, 
Ranunculaceae, Thalictrum, Caryophyllaceae, Cyperaceae, Rosaceae, Gramineae, Leguminosae and Umbelliferae. Temperature and precipitation data from 1951 to 2006 were collected from 6 weather stations (Fukang, Qitai, Urumqi, Tianchi, Xiaoquzi, Daxigou) on the north slope of the Middle Tianshan Mountains. These data were used to calculate correlation coefficients with pollen data and to analyze the monthly wind direction frequencies from 2001 to 2006 in these areas.

Table 1 Characteristics of vegetation and pollen assemblage of surface soil layer along the altitudinal transect on the north slope of the Middle Tianshan Mountains

\begin{tabular}{|c|c|c|c|c|c|c|}
\hline $\begin{array}{l}\text { Vegetation } \\
\text { zone }\end{array}$ & $\begin{array}{l}\text { No. of } \\
\text { quadrat }\end{array}$ & $\begin{array}{l}\text { Elevation } \\
\qquad(\mathrm{m})\end{array}$ & $\begin{array}{l}\text { Dominant species } \\
\text { (coverage }(\%))\end{array}$ & $\begin{array}{l}\text { Pollen } \\
\text { zone }\end{array}$ & $\begin{array}{l}\text { No. of } \\
\text { pollen } \\
\text { samples }\end{array}$ & $\begin{array}{l}\text { Dominant pollen taxa } \\
\text { (percentage }(\%))\end{array}$ \\
\hline $\begin{array}{l}\text { 1, alpine } \\
\text { cushion }\end{array}$ & Nill & $>3,500$ & $\begin{array}{l}\text { Thylacospermum caespitosum, } \\
\text { Potentilla biflora (total } \\
\text { coverage } 25-60 \text { ) }\end{array}$ & I & 1 & $\begin{array}{l}\text { Tree pollen (20.6): Picea (11.4), Salix } \\
(8.7) \text {, Betula }(0.5) \text {; Shrub pollen } \\
\text { (14.3): Ephedra }(11.4) \text {, Nitraria }(7.4) \text {; } \\
\text { Herb pollen }(65.1) \text {, Artemisia }(37.3) \text {, } \\
\text { Chenopodiaceae }(16.2) \text {, Compositae, } \\
\text { Thalictrum, Ranunculaceae, } \\
\text { Caryophyllaceae, Gramineae (1.2- } \\
\text { 2.7) }\end{array}$ \\
\hline $\begin{array}{l}2, \text { alpine and } \\
\text { subalpine } \\
\text { meadow }\end{array}$ & $1-17$ & $3,390-2,600$ & $\begin{array}{l}\text { Poa } 3.3(0-13.5), \text { Festuca } 10.2 \\
(0-30), \text { Carex } 16.2(0-38.4), \\
\text { Thalictrum } 4.0(0-15), \\
\text { Polygonum viviparum } 8.8 \\
(1.3-21.6)\end{array}$ & II & $2-20$ & $\begin{array}{l}\text { Tree pollen (20.6-43.8): Picea } 29.8 \\
(11.4-40.0) \text {, Salix 5.1 }(2.5-9.4) \text {; } \\
\text { Shrub pollen }(1.3-13.8) \text { : Ephedra } 8.5 \\
(0-11.4) \text {, Tamaricaceae } 1.4(0-4.9) \text {, } \\
\text { Nitraria 0.6 }(0-2.4) \text {; Herb pollen } \\
(43.6-65.6) \text { : Chenopodiaceae } 20.4 \\
(12.7-24.7), \text { Artemisia } 18.3(11.6- \\
37.3) \text {, Compositae } 0.9(0-2.7) \text {, } \\
\text { Gramineae } 0.9(0-2.2), \text { Thalictrum } \\
3.5(1.9-6) \text {, Caryophyllaceae } 4.4 \\
(0.9-21.7) \text {, Ranunculaceae } 1.5(0.8- \\
2.5)\end{array}$ \\
\hline $\begin{array}{l}\text { 3, Tianshan } \\
\text { spruce forest }\end{array}$ & $18-37$ & $2,600-1,800$ & $\begin{array}{l}\text { Aegopodium alpestre } 12.9(0- \\
32.5), \text { Calamagrostis } \\
\text { arundinacea } 1.9(0-9.6), \\
\text { Cicerbita azurea } 7.7(0-25.4) \text {, } \\
\text { Picea schrenkiana } 59.2(27.3- \\
84.4), \text { Poa } 1.0(0-2.5), \\
\text { Thalictrum } 0.8(0-3.8)\end{array}$ & III & $21-47$ & $\begin{array}{l}\text { Tree pollen } 66.2(22.6-94.0) \text { : Picea } \\
62.4(10.4-93.3) \text {, Salix } 3.2(0.7-11.5) \text {; } \\
\text { Shrub pollen } 7.1(1.4-24.6) \text { : Ephedra } \\
4.1(0.7-10.8) \text {, Tamaricaceae } 2.8(0- \\
\text { 13.9); Herb pollen } 26.7(4.6-52.8) \text { : } \\
\text { Chenopodiaceae } 12.7(1.8-25.4) \text {, } \\
\text { Artemisia } 6.7(0.7-12.4)\end{array}$ \\
\hline $\begin{array}{l}4, \text { forest- } \\
\text { steppe ecotone }\end{array}$ & $38-50$ & $1,720-1,300$ & $\begin{array}{l}\text { Aegopodium alpestre } 7.4 \text { ( } 0 \text { - } \\
\text { 30.6), Calamagrostis } \\
\text { arundinacea } 6.1(0-19.2), \\
\text { Artemisia } 4.9(0.1-32.5) \text { Carex } \\
8.9(0-33.8), \text { Cotoneaster } 12.9 \\
(0-39.8), \text { Fragaria viridis } 4.7 \\
(0-41.3), \text { Galium boreale } 2.7 \\
(0-13.6), \text { Geranium pratense } \\
2.1(0-5.4), \text { Lonicera } 4.6(0- \\
16.1), \text { Poa } 2.9(0-13.8), \text { Rosa } \\
16.9(0.1-56.8), \text { Sorbus } \\
\text { tianschanica } 3.5(0-22.9), \\
\text { Salix } 2.9(0-22.7), \text { Picea } \\
\text { schrenkiana } 17.5(0-86.5), \\
\text { Senecio nemorensis } 3.5(0- \\
15.3), \text { Spiraea } 2.8(0-16.4), \\
\text { Thalictrum } 1.7(0-4.3)\end{array}$ & IV & & $\begin{array}{l}\text { Tree pollen } 23.2(20-27.6) \text { : Picea } \\
14.7(10-23.4) \text {, Salix } 7.1(3.2-11.3) \text {; } \\
\text { Shrub pollen } 21.1(16.9-23.5) \text { : } \\
\text { Ephedra } 11.1(7.7-15) \text {, Tamaricaceae } \\
9.4(6.8-15.3) \text {; Herb pollen } 55.7(50- \\
63.1) \text { : Chenopodiaceae } 27.1(23.7- \\
\text { 29.6), Artemisia } 15.4(11.6-22) \text {, } \\
\text { Thalictrum } 3.7(1-9.6)\end{array}$ \\
\hline $\begin{array}{l}\text { 5, Artemisia } \\
\text { desert }\end{array}$ & $51-63$ & $1,230-700$ & $\begin{array}{l}\text { Artemisia rupestris } 14.5(0.3- \\
54.4), \text { Festuca } 2.8(0-10.1) \text {, } \\
\text { Gleiditsia } 16.5(0-38.7), \text { Carex } \\
5.4(0-33.8)\end{array}$ & $\mathrm{V}$ & $48-59$ & $\begin{array}{l}\text { Tree pollen } 11.1(7.9-16) \text { : Picea } 3.7 \\
(0.7-9.3) \text {, Salix } 6.2(3.7-11.2) \text {; Shrub } \\
\text { pollen } 12.6(9.1-19.2) \text { : Ephedra } 5.6 \\
(2.4-12.5) \text {, Tamaricaceae } 6.7(4-10) \text {; } \\
\text { Herb pollen } 76.3(64.7-81.8) \text { : } \\
\text { Chenopodiaceae } 18(9.5-28) \text {, } \\
\text { Artemisia } 53(31.2-61.5)\end{array}$ \\
\hline $\begin{array}{l}6 \text {, typical } \\
\text { desert }\end{array}$ & $64-86$ & $620-460$ & $\begin{array}{l}\text { Artemisia rupestris } 7.6(0- \\
64.6), \text { Haloxylon } \\
\text { ammodendron } 3.5(0-41.2) \text {, } \\
\text { Petrosimonia sibirica } 4.8(0- \\
\text { 32.6), Salsola } 4.5(0-65), \\
\text { Suaeda physophora } 2.9(0- \\
\text { 26.3), Reaumuria } 6.9(0-20) \text {, } \\
\text { Tamarix hispida } 3.3(0-27)\end{array}$ & VI & $60-80$ & $\begin{array}{l}\text { Tree pollen } 16.6(8.2-27.6) \text { : Picea } 1.7 \\
(0.6-4.2), \text { Salix } 4.5(0.9-6.9) \text {, Ulmus } \\
10(2.5-20.2) \text {; Shrub pollen } 11.6(4.7- \\
28.1) \text { : Ephedra } 4.2(1.4-10.3) \text {, } \\
\text { Tamaricaceae } 6.6(3.2-17.2) \text {; Herb } \\
\text { pollen } 71.8(51.7-84) \text { : } \\
\text { Chenopodiaceae } 49.3(25.4-72.4) \text {, } \\
\text { Artemisia } 17(5.4-40.1), \text { Thalictrum } \\
1.5(0.3-3.6)\end{array}$ \\
\hline
\end{tabular}




\section{Results}

\subsection{Pollen assemblages in surface soil layer}

More than 32,502 pollen-spore grains were counted; families and genera were identified as 24 and 31, respectively. The altitudinal pollen spectra can be divided into 6 pollen zones (Fig. 3) according to modern vegetation survey and the characteristics of pollen spectra.

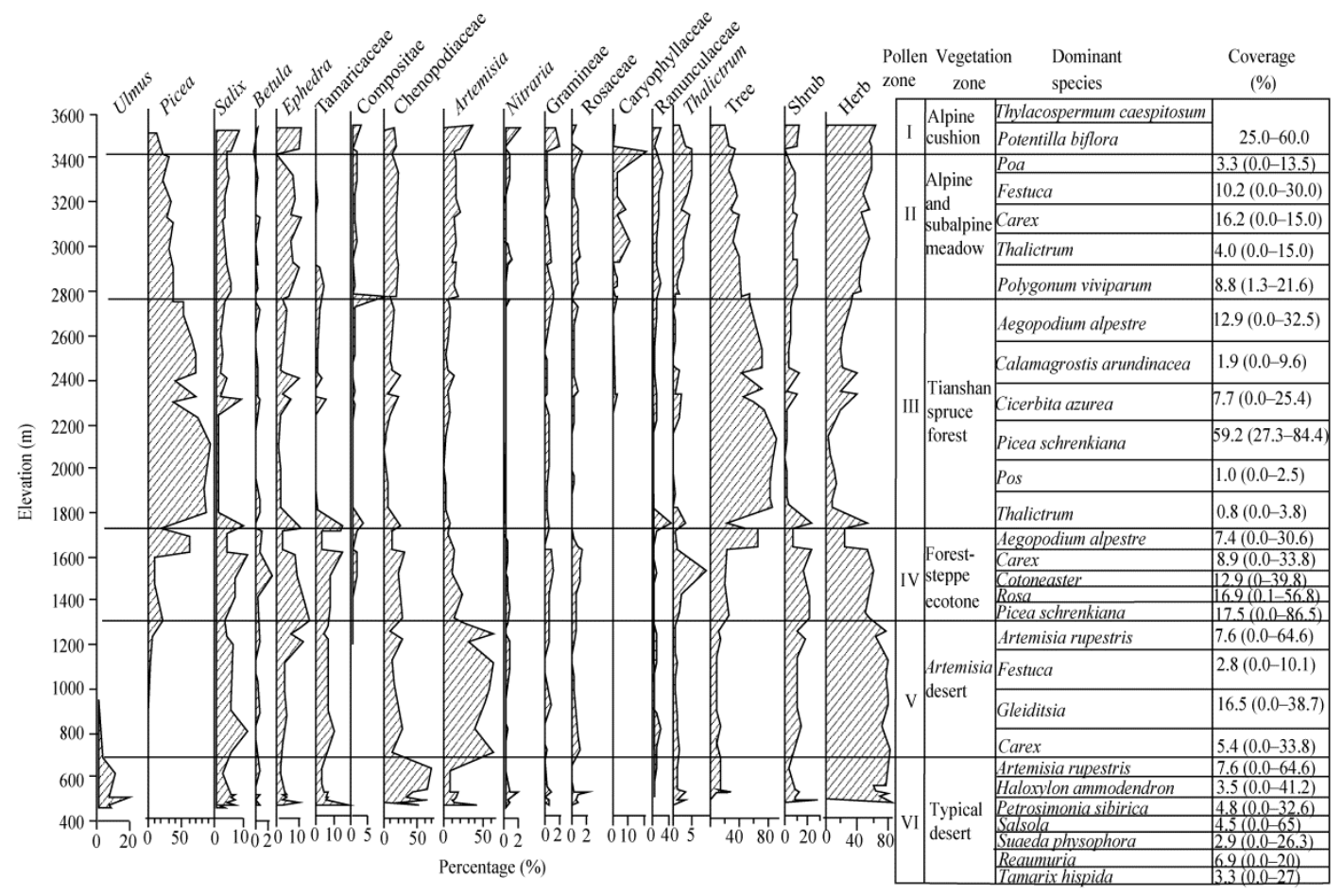

Fig. 3 Pollen assemblages in surface soil layers (percentage) along the altitudinal transect on the north slope of the Middle Tianshan Mountains

\subsubsection{Pollen zone I: Alpine cushion vegetation}

This zone is between 3,510 to $3,420 \mathrm{~m}$, herb pollen accounts for a large proportion $(65.1 \%)$ and dominated by Artemisia (37.3\%) and Chenopodiaceae (16.2\%). A small amount of Compositae, Thalictrum, Ranunculaceae, Caryophyphyllaceae and Gramineae are identified $(1.2 \%-2.7 \%)$. Tree pollen accounts for $20.6 \%$ and is dominated by Picea $(11.4 \%)$ and Salix $(8.7 \%)$ with sparse Betula pollen (0.5\%). Shrub pollen accounts for $14.3 \%$ and is dominated by Ephedra $(11.4 \%)$ and Nitraria $(7.4 \%)$.

\subsubsection{Pollen zone II: Alpine and subalpine meadow}

This pollen zone is well defined by the high content of herb pollen $(43.6 \%-65.6 \%)$. Chenopodiaceae (12.7\%-24.7\%) and Artemisia (11.6\%-37.3\%) are dominant pollen, but they are found in the modern vegetation between 3,420 to 2,755 m. Similarly, tree pollen such as Picea, Salix and Betula, shrub pollen such as Ephedra and Nitraria also account for a relative high proportion, but they cannot be found in modern vegetation as well. The dominant pollen taxa such as Poa, Festuca, Carex, Thalictrum and Polygonum viviparum do exist in modern vegetation.

\subsubsection{Pollen zone III: Montane Picea forest}

This zone has the highest content of Picea pollen $(10.4 \%-93.3 \%)$ with the lowest content of shrub and herb pollen. Between the elevations of 2,755-1,720 m within the Picea forest, mean Picea pollen content is $62.4 \%$ and the mean coverage of Picea forest is $52.5 \%$. Picea pollen content reaches the highest amount of $93.3 \%$ at the elevation of $2,100 \mathrm{~m}$. 


\subsubsection{Pollen zone IV: Forest-steppe ecotone}

This zone is between $1,720-1,230 \mathrm{~m}$ and characterized by high content of herb pollen $(50.0 \%-$ $63.1 \%$ ) and shrub pollen (16.9\%-23.5\%). Picea pollen content abruptly declines to $10 \%-20 \%$. The percentage of tree pollen, such as Salix and Betula, increases. Shrub pollen percentage such as Ephedra and Tamaricaceae is also higher than that in zone III. Herb pollen occupies the largest proportion in this zone, dominated by Artemisia, Chenopodiaceae, Thalictrum, Compositae and Ranunculaceae. These shrub and herb pollen come from shrub species of Rosa platyacantha Schrenk, Rosa albertii, Cotoneaster melanocarpus, Caragana pleiophylla and Lonicera hispida (accounting for $47.4 \%$ of shrub layer), and herb species of Calamagrostis arundinacea, Agropyron cristatum, Elymus dahuricus, Poa annua, Calamagrostis epigeios, Festuca ovina, Aegopodium alpestre, Carex, Artemisia, Senecio nemorensis and Heteropappus altaicus (accounting for $84.8 \%$ of herb layer).

\subsubsection{Pollen zone V: Artemisia desert}

Relatively high content of Artemisia pollen (31.2\%-61.5\%), low content of arboreal, shrub and other herb pollen distinguish the vegetation belt in 1,230-620 m. Picea pollen only occupies $1 \%-$ $5 \%$ of tree pollen. However, the percentages of Salix and Ulmus pollen increase, whereas shrub pollen of Ephedra, Tamaricaceae and Nitraria decrease compared to those in zone III. Herb pollen is dominated by Artemisia and Chenopodiaceae.

\subsubsection{Pollen zone VI: Typical desert}

Chenopodiaceae pollen $(25.4 \%-72.4 \%)$ absolutely dominated the area below $620 \mathrm{~m}$, reflecting the typical desert vegetation is dominated by herb and shrub species of Chenopodiaceae, such as Petrosimonia sibirica (0-32.6\%), Suaeda physophora (0-26.3\%), Reaumuria (0-26.3\%), Tamarix hispida (0-27.0\%) and Haloxylon ammodendron (0-41.2\%).

\subsection{Pollen ratio}

As shown in Fig. 4, Chenopodiaceae/Artemisia (C/A value) is the lowest in the Artemisia desert, showing that the percentage of Artemisia pollen is greatly higher than that of Chenopodiaceae. In addition, the value reaches the maximum in the typical desert, making it clear that Chenopodiaceae has the greatest value in this pollen zone. Most of $\mathrm{C} / \mathrm{A}$ values are greater than 1 at the elevation of above 1,300 m. Between 1,300-700 $\mathrm{m}$ in the Artemisia desert, C/A values are smaller than 1. C/A value suddenly increases below $700 \mathrm{~m}$ and reaches 13.5 at $620 \mathrm{~m}$. Chenopodiaceae dominated desert vegetation in this region where the annual precipitation is $100-300 \mathrm{~mm}$ (Zhou, 1995). Montane spruce forest zone has the highest content of arboreal pollen. Besides this zone, arboreal pollen/non-arboreal pollen (AP/NAP) values are all extremely low.
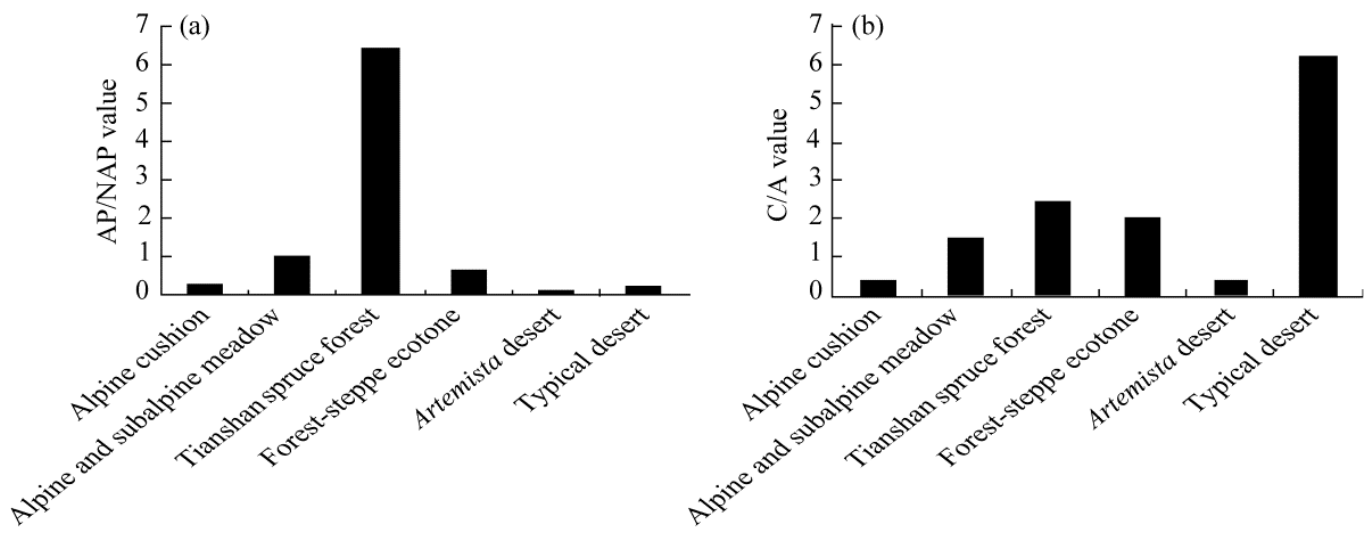

Fig. 4 Arboreal pollen/non-arboreal pollen (AP/NAP value; a) and Chenopodiaceae/Artemisia (C/A value; b) ratio along the altitudinal transect on the north slope of the Middle Tianshan Mountains 


\subsection{Pollen assemblages and environmental variables}

DCA was used to analyze the relationships between the pollen assemblages and environmental variables using CANOCO 4.5. DCA results (Fig. 5) revealed that the first two axes captured $57.1 \%$ of the variance in the pollen data (axis 1, 46.8\%; axis 2, 10.3\%). The eigenvalues of the first two axes are obviously higher than those of the second two axes, indicating that pollen data are controlled by two environmental factors represented by axis 1 and axis 2 . Figure 5 shows that pollen zones I, V and VI are distinct from the other pollen zones. There are correspondences between the zone I and Rosaceae; the zone II and Compositae; the zone III and Picea; the zone IV and Ephedra and Cyperaceae; the zone V and Artemisia; and the zone VI and Chenopodiaceae. With respect to pollen taxa, Picea shows lower scores on axis 1, whereas typical desert vegetation types such as Chenopodiaceae and Artemisia have a higher value, showing that Axis 1 represents the changes of humidity. In axis 2, Artemisia has the lowest value and Chenopodiaceae has the highest value. Moreover, a distribution mode of one center (humid region vegetation type, all kinds of meadow and Picea schrenkiana forest) and two apices (two drought poles, the Artemisia desert and typical desert) were shown in Fig. 5, reflecting the humidity changes on the north slope of the Middle Tianshan Mountains.

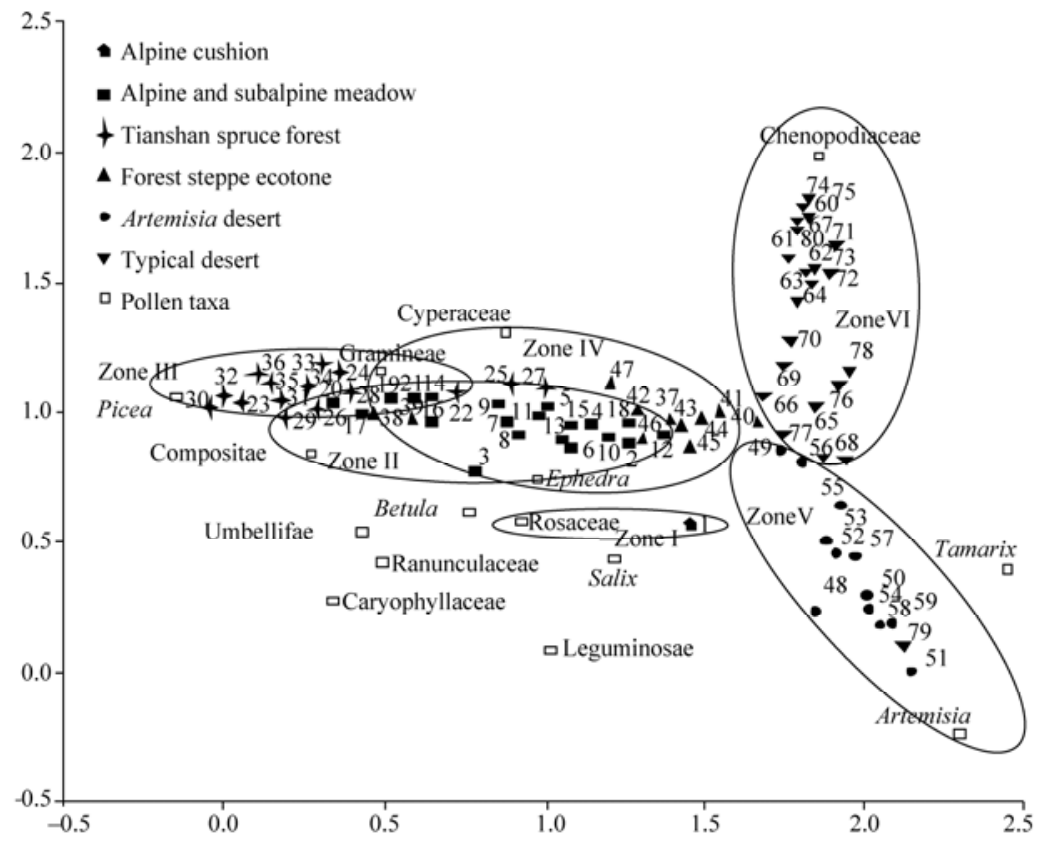

Fig. 5 Detrended correspondence analysis results of pollen assemblages of the surface soil sampling sites and pollen taxa

\section{Discussion}

\subsection{The relationship between surface pollen and modern vegetation}

DCA results revealed that the indicative taxa of pollen zone I is Rosaceae and the coverage of Potentilla biflora is relatively high in this zone. The indicative taxa of zone II is Compositae and the mean vegetation cover of the species is also very high in this zone. Picea percentage in surface soils is $40 \%-90 \%$ at the elevation of $2,800-1,800 \mathrm{~m}$ in the distributional range of Picea forest vegetation zone, but it has a higher content only below the lower limit of Picea forest $(<1,800 \mathrm{~m})$. Deciduous tree pollen of Salix and Betula appear in all pollen zones with very low contents of ca. $5 \%$ and $1 \%$, respectively. Ulmus pollen only appears at the elevation below 1,600 $\mathrm{m}$ while Ephedra pollen was found at all elevations with higher contents in non-forest elevations (ca. $6 \%-8 \%)$ than in forest elevations $(2 \%-6 \%)$. Compositae pollen appears at all elevations with 
higher percentage at high $(3,500-2,800 \mathrm{~m})$ and middle $(1,800-1,400 \mathrm{~m})$ elevations. Other herb pollen such as Graminaceae, Thalictrum, Ranunculaceae and Rosaceae appear in all elevations with low contents. Pollen of Caryophyllaceae only appears in high elevation of 3,500-2,800 m. Nitraria pollen mostly appears in non-forest elevations. Pollen of Chenopodiaceae and Artemisia occur in all of elevation with high contents of ca. $10 \%-70 \%$ and $10 \%-60 \%$, respectively, but their contents at forest elevations are higher than those at non-forest elevations. The highest content appears in the low elevations, especially in the desert zone.

Surface pollen assemblages basically reflect the characteristics of modern vegetation. Among all pollen, considerable amount of pollen comes from vegetation in original places. For example, Picea pollen is more than 50\% in Picea forest stand and less than 5\% in desert. Mean content of Artemisia pollen is 53\% in Artemisia desert and Chenopodiaceae pollen is $49 \%$ in typical desert.

However, pollen assemblages of surface soil layer don't well reflect the modern vegetation in some places. For example, at 3,400 to $2,700 \mathrm{~m}$ in the area of meadow vegetation, pollen assemblage is dominated by Picea within the range of $11 \%-40 \%$. The elevation of $2,600-2,700 \mathrm{~m}$ is the upper limit for modern Picea forest. Therefore, Picea pollen in the meadow vegetation above 2,700 m might be introduced from spruce forest stand below 2,700 m. Similarly, spruce tree is absent in the desert zone, but its pollen percentage is more than $1 \%$.

\subsection{Typical arboreal pollen and vegetation}

Airborne pollen is produced by the flowering plants. Therefore, airborne pollen amount during the period of peak florescence can reflect the characteristics of modern vegetation within a radius of about $50 \mathrm{~km}$ in this area. During the period of July 2001 to July 2006, airborne pollen rain samples were collected from Tianchi Meteorological Station $\left(43^{\circ} 53^{\prime} 58.38^{\prime \prime} \mathrm{N}, 8^{\circ} 07^{\prime} 15.75^{\prime \prime} \mathrm{E}\right.$; $1,942.5 \mathrm{~m}$ asl), Fukang Desert Ecosystem Observation and Experiment Station (44 $17^{\prime} 27.41^{\prime \prime} \mathrm{N}$, $87^{\circ} 55^{\prime} 52.65^{\prime \prime} \mathrm{E}$; $477 \mathrm{~m}$ asl) and Beishawo Grass Peat Experimental Field Station (44 $22^{\prime} 40.74^{\prime \prime} \mathrm{N}$, $87^{\circ} 55^{\prime} 9.74^{\prime \prime} \mathrm{E}$; $443 \mathrm{~m}$ asl) through three sets of airborne pollen trap on the north slope of Tianshan Mountains (Yang, 2004; Mao, 2008; Pan et al., 2011).The results indicate that the percentage and volume concentration of Picea pollen obviously change along the altitudinal gradient, reaching its peak value in the Tianchi area (Picea forest), with an average of $21.2 \%$. About $50 \%$ of the spruce pollen grains were collected at the beginning of June, and the pollen concentration decreased to $1.8 \%$ in Fukang and Beishawo areas at lower elevations (Table 2), which is in accordance with surface pollen assemblage characteristics.

Table 2 Pollen percentages of main taxa from atmosphere and surface soil and local vegetation covers (Yang, 2004; Mao, 2008)

\begin{tabular}{|c|c|c|c|c|c|c|c|c|}
\hline \multirow{3}{*}{ Pollen type } & \multicolumn{5}{|c|}{ Tianchi area (Picea forest zone) } & \multirow{2}{*}{\multicolumn{3}{|c|}{$\begin{array}{c}\text { Beishawo, Fukang (average) } \\
\text { Airborne pollen }(\%)\end{array}$}} \\
\hline & \multicolumn{3}{|c|}{ Airborne pollen $(\%)$} & \multirow{2}{*}{$\begin{array}{l}\text { Surface } \\
\text { soil } \\
\text { pollen } \\
(\%)\end{array}$} & \multirow{2}{*}{$\begin{array}{c}\text { Vegetation } \\
\text { coverage } \\
(\%)\end{array}$} & & & \\
\hline & Summer & Autumn & $\begin{array}{c}\text { Average of } \\
5 \text { years }\end{array}$ & & & Summer & Autumn & $\begin{array}{l}\text { Average } \\
\text { of } 5 \\
\text { years }\end{array}$ \\
\hline Picea & 33.0 & 2.4 & 21.2 & 62.4 & 53.7 & 1.8 & 0.3 & 1.1 \\
\hline Chenopodiaceae & 20.9 & 18.1 & 12.4 & 12.7 & 0.0 & 60.6 & 33.7 & 57.2 \\
\hline Artemisia & 24.2 & 64.0 & 49.1 & 6.7 & $<0.1$ & 10.4 & 48.9 & 22.1 \\
\hline
\end{tabular}

The content of Picea in Zone III reaches $62.4 \%$, which is corresponding with its vegetation coverage (53.7\%). In Zone I and II, surface pollen assemblages are also dominated by Picea $(11 \%-40 \%)$, but the elevation is higher than the upper limit of modern Picea forest. This phenomenon is likely caused by anabatic wind. Air current in the valley contributes mostly to such pollen transportation, which has been confirmed by previous studies (Li, 1991; Yan et al., 2004). As the edificator of coniferous forest in the northern Xinjiang, the dispersal and transportation of Picea pollen are quite distinct (Rousseau et al., 2003). According to the meteorological data at Tianchi from 2001 to 2006, the wind directions in this area were dominated by northwest or southeast winds. The frequency of southeast mountain wind is low from June to August while the northwest valley wind reaches the highest value in the transition of 
spring and summer due to the special mountain and valley topography and has a remarkable influence on the transport and dispersion of pollen. The peak concentration of Picea pollen appears in early summer. As a result, Picea pollen percentage above the upper limit of Picea forest is higher than that below the lower limit of Picea forest stand. Studies in the California Inyo Mountains (Solomon and Silkworth, 1986), the Colorado Rocky Mountains (Fall, 1992b), the Niederhorn mountain/valley system (Markgraf, 1980) and in the central Jordan Rift (Davies and Fall, 2001) also demonstrated the conclusions (Fig. 3).

In addition, according to the results of correlation coefficient between airborne pollen concentration and wind velocity, the correlation coefficient of Picea is 0.394 with a significant correlation level at 0.05 . In the study area, wind velocity is getting higher from April to June during the full-bloom stage of Picea and the pollen grains are easily carried upwards, which leads to the high content of Picea pollen above the upper limit of modern Picea forest. While in other seasons, the wind direction turns from northwest to southeast and the production of Picea is relatively low. As a consequence, there is a small amount of pollen carried from high elevation to the lower areas.

\subsection{Typical herb pollen and vegetation}

Chenopodiaceae and Artemisia are dominant species in the desert communities with high pollen percentage. The relationship between Chenopodiaceae, Artemisia and the amount of their pollen explains the connection of surface pollen assemblage and desert vegetation. Previous investigations in Xinjiang showed that when the vegetation coverage of some dominant species reaches $30 \%$, their pollen content is equal to their coverage. But if a low coverage and a high pollen content appear together, it likely results from a large production of pollen grains. However, it is easy to understand the relationship between their plants and pollen of Chenopodiaceae and Artemisia because their pollen grains mostly fall around the plant. In the Artemisia desert along the transect, Artemisia pollen content is $31.2 \%-64.0 \%$ and the coverage of Artemisia species is $0.3 \%-33.4 \%$; in typical desert, Chenopodiaceae pollen content is $25.4 \%-72.4 \%$ and their plant coverage is $5.6 \%-56.3 \%$. Therefore, when pollen assemblage is dominated by Chenopodiaceae and Artemisia, their pollen amounts reflect the modern vegetation characteristics. High amounts of Artemisia pollen spectra represent Artemisia desert vegetation landscape. In contrast, the desert at lower elevations is characterized by the great amount of Chenopodiaceae pollen. Airborne pollen from the north slope of the Tianshan Mountains (Yang, 2004; Mao, 2008) showed that Chenopodiaceae and Artemisia are over-represented in Tianchi area. But in Beishawo area, Chenopodiaceae is well-represented, just as the Artemisia in Fukang area, which was demonstrated by Li et al. (2005). Species of Chenopodiaceae and Artemisia in modern vegetation above 1,230 m don't appear frequently but their pollen amounts are not low in pollen assemblages (Fig. 3). The researches of airborne pollen in the Tianchi area proved that the major portion of Chenopodiaceae and Artemisia pollen are brought from Artemisia desert and typical desert by updraft (Yang, 2004).

\section{Conclusions}

This research demonstrated a strong relationship between vegetation and surface pollen spectra along the transect from 3,510 to $460 \mathrm{~m}$ on the north slope of the Middle Tianshan Mountains.

Pollen assemblages in the surface soil layers basically reflect the characteristics of the mountainous vegetation patterns on the north slope of the Middle Tianshan Mountains. Among all pollen, considerable amount of surface pollen come from vegetation in original places. However, there are some differences between surface pollen spectra and vegetation zones. Some boundaries of pollen assemblage and modern vegetation zone are different, for example, the elevational span of Picea pollen zone is higher than that of Picea forest. Percentages of Picea, Chenopodiaceae and Artemisia pollen are much higher than their relative coverage in modern vegetation. They have over-representation. Moreover, Picea pollen exists outside the Picea forest, and Chenopodiaceae and Artemisia pollen are distributed above 1,300 $\mathrm{m}$ elevation, indicating that 
most of them are foreign pollen carried by updraft.

When pollen assemblage is dominated by Chenopodiaceae and Artemisia, their pollen amount can be used to define modern vegetation characteristics. In this case, the pollen percentages and taxa coverage in modern vegetation are basically equivalent. Therefore, the ratio of Chenopodiaceae to Artemisia in pollen assemblage can reflect arid characteristics of modern vegetation in arid area.

Most pollen and spore are dispersed by the highly-frequent northwester wind on the north slope of the Tianshan Mountains. It is proved by the results of airborne pollen research in three different elevation regions on the north slope of the Middle Tianshan Mountains. The Picea pollen of spruce forest and eremophytes pollen at lower elevations are usually transported to higher elevations. It is difficult to recognize vegetation patterns on the basis of surface pollen assemblage in the high elevation zones. Therefore, the modern vegetation and long distance wind transport must be taken into account for the interpretation of surface pollen in the Quaternary sediment analysis.

\section{Acknowledgements}

This research was jointly funded by the National Natural Science Foundation of China (40972212, 41272386, 41572331, 90102009, 31590822), the Scientific Research Foundation for the Young Scientists of State Key Laboratory of Vegetation and Environmental Change, Institute of Botany, Chinese Academy of Sciences and the Returned Overseas Chinese Scholars, Ministry of Education of the People's Republic of China and the National Postdoc Science Foundation of China (2003033253). We are also grateful to Mr LIU Haijiang for TWINSPAN classification and Ms LI Xiaoxiang for drawing Fig. 1.

\section{References}

Berrio J C, Arbelaez M V, Duivenvoorden J F, et al. 2003. Pollen representation and successional vegetation change on the sandstone plateau of Araracuara, Colombian Amazonia. Review of Palaeobotany and Palynology, 126(3-4): $163-181$.

Caseldine C, Pardoe H. 1994. Surface pollen studies from alpine sub-alpine southern Norway: applications to Holocene data. Review of Palaeobotany and Palynology, 82(1-2): 1-15.

Chen Y, Ni J, Herzschuh U. 2010. Quantifying modern biomes based on surface pollen data in China. Global and Planetary Change, 74(3-4): 114-131.

Comprehensive Investigation Team of Xinjiang and Institute of Botany, Chinese Academy of Sciences. 1978. Xinjiang Vegetation and its Utilization. Beijing: Science Press, 378. (in Chinese)

Dai L, Weng C Y. 2011. A survey on pollen dispersal in the western Pacific Ocean and its paleoclimatological significance as a proxy for variation of the Asian winter monsoon. Science China-Earth Sciences, 54(2): 249-258.

Davis M B. 1963. On the theory of pollen analysis. American Journal of Science, 261: 897-912.

Davies C P, Fall P L. 2001. Modern pollen precipitation from an elevational transect in central Jordan and its relationship to vegetation. Journal of Biogeography, 28(10): 1195-1210.

Dupont L M, Wyputta U. 2003. Reconstructing pathways of aeolian pollen transport to the marine sediments along the coastline of SW Africa. Quaternary Science Reviews, 22: 157-174.

Editorial Committee for Forests of Xinjiang. 1989. Forests of Xinjiang. Beijing: China Forestry Press, 10-577. (in Chinese)

El-Moslimany A P. 1990. Ecological significance of common non-arboreal pollen: examples from drylands of the Middle East. Review of Palaeobotany and Palynology, 64(1): 343-350.

Fall P L. 1992a. Pollen accumulation in a montane region of Colorado, USA: a comparison of moss polsters, atmospheric traps, and natural basins. Review of Palaeobotany and Palynology, 72(3-4): 169-197.

Fall P L. 1992b. Spatial patterns of atmospheric pollen dispersal in the Colorado Rocky Mountains, USA. Review of Palaeobotany and Palynology, 74(3): 293-313.

Fontana S L. 2003. Pollen deposition in coastal dunes, south Buenos Aires Province, Argentina. Review of Palaeobotany and Palynology, 126(126): 17-37.

Herzschuh U, Birks H J B. 2010. Evaluating the indicator value of Tibetan pollen taxa for modern vegetation and climate. Review of Palaeobotany and Palynology, 160(3-4):197-208.

Hill M O. 1979. TWINSPAN: A FORTRAN Program for Arranging Multivariate Data in an Ordered Two-way Table by 
Classification of the Individuals and Attributes. Ithaca, NY, Cornell University, 1-90.

Jackson S T., 1990. Pollen source area and representation in small lakes of the northeastern United States. Review of Palaeobotany and Palynology 63(1-2): 53-76.

Jackson S T, Dunwiddie P W. 1992. Pollen dispersal and representation on an offshore island. New Phytologist 122(1): 187202.

Larocque I, Campbell I, Bradshaw, R H W, et al. 2000. Modern pollen-representation of some boreal species on islands in a large lake in Canada. Review of Palaeobotany and Palynology, 108(3-4): 197-211.

Li G Y, Qian Z S, Hu Y. 1995. Palynological Analysis Manual. Beijing: Geological Publishing House, 223. (in Chinese)

Li M Y, Li Y C, Xu Q H, et al. 2012. Surface pollen assemblages of human-disturbed vegetation and their relationship with vegetation and climate in Northeast China. Chinese Science Bulletin, 57(5): 535-547.

Li W Y, Yan S. 1990. Quaternary spore-pollen study of the Chaiwopu Basin. In: Shi Y F, Wen Q Z, Qu Y G. The Quaternary Climo-Environment Changes and Hydrogeological Condition on the Chaiwopu Basin in Xinjiang Region. Beijing: China Ocean Press, 46-74. (in Chinese)

Li W Y. 1991. Dispersal efficiency of Picea pollen. Acta Botanica Sinica, 33: 792-800. (in Chinese)

Li W Y. 1998. Vegetation and Environment of Quaternary in China. Beijing: Science Press, 253. (in Chinese)

Li Y C, Bunting J M, Xu Q H, et al. 2011. Pollen-vegetation-climate relationships in some desert and desert-steppe communities in northern China. Holocene, 21(6): 997-1010.

Lu H Y, Wu N Q, Liu K B, et al. 2011. Modern pollen distributions in Qinghai-Tibetan Plateau and the development of transfer functions for reconstructing Holocene environmental changes. Quaternary Science Reviews, 30(7-8): 947-966.

Luo C X, Zheng Z, Tarasov P, et al. 2009. Characteristics of the modern pollen distribution and their relationship to vegetation in the Xinjiang region, northwestern China. Review of Palaeobotany and Palynology, 153 (3-4): 282-295.

Mao L M. 2008. Temporal and spatial variations of atmospheric pollen quantity and its climatic and vegetational significance in the central northern Tianshan Mountains, Xinjiang. PhD Dissertation. Beijing: Institute of Botany, Chinese Academy of Sciences. (in Chinese)

Markgraf V. 1980. Pollen dispersal in a mountain area. Grana, 19(19): 127-146.

McGlone M S, Moar N T. 1997. Pollen-vegetation relationships on the subantarctic Auckland Islands, New Zealand. Review of Palaeobotany and Palynology, 96(96): 317-338.

Newsome J C. 1999. Pollen-vegetation relationships in semi-arid southwestern Australia. Review of Palaeobotany and Palynology, 106(1-2): 103-119.

Pan A D. 1993. Research on sporo-pollen assemblages in surface soils of various vegetation on northern slope of the Tianshan Mountains. Scientia Geographica Sinica, 3: 227-233. (in Chinese)

Pan Y F, Yan S, Mu G J, et al. 2011. Changes in the concentrations of airborne Picea schrenkiana pollen in response to temperature changes in the Tianshan Mountain area. Acta Ecologica Sinica. 31(23): 6999-7006. (in Chinese)

Rousseau D D, Duzer D, Cambon G V, et al. 2003. Long distance transport of pollen to Greenland. Geophysical Research Letters, 30(14): ASC 12-1.

Smirnov A, Chmura G L, Lapointe M F, 1996. Spatial distribution of suspended pollen in the Mississippi River as an example of pollen transport in alluvial channels. Review of Palaeobotany and Palynology, 92(92): 69-81.

Solomon A M, Blasing T J, Solomon J A. 1982. Interpretation of floodplain pollen in alluvial sediments from an arid region. Quaternary Research, 18: 52-71.

Solomon A M, Silkworth A B. 1986. Spatial patterns of atmospheric pollen transport in a montane region. Quaternary Research, 25: $150-162$.

Stutz S, Prieto A R. 2003. Modern pollen and vegetation relationships in Mar Chiquita coastal lagoon area, southeastern Pampa grasslands, Argentina. Review of Palaeobotany and Palynology, 126(s 3-4): 183-195.

Sun X J, Du N Q, Weng C Y, 1994. Paleovegetation and paleoenvironment of Manasi Lake, Xinjiang, NW China during the last 14000 years. Quaternary Research, 3:239-247. (in Chinese)

ter Braak C J F, Šmilauer P, 2002. CANOCO Reference Manual and CanoDraw for Windows User's Guide: Software for Canonical Community Ordination (version 4.5). Ithaca, NY, Microcomputer Power.

Walker D. 2000. Pollen input to, and incorporation in, two crater lakes in tropical northeast Australia. Review of Palaeobotany and Palynology, 111(3-4): 253-283.

Wang F X, Qian N F, Zhang Y L, et al. 1995. Pollen Flora of China (2 ${ }^{\text {nd }}$ ed.). Beijing: Science Press, 461. (in Chinese)

Wang S M, Ji L, Yang X D et al. 1995. Paleolimnology of Hulun Lake. Hefei: Chinese Technology University Press, 42-75. (in Chinese)

Wilmshurst J M, McGlone M S. 2005. Origin of pollen and spores in surface lake sediments: comparison of modern 
palynomorph assemblages in moss cushions, surface soils and surface lake sediments. Review of Palaeobotany and Palynology, 136 (1-2): 1-15.

Xi Y Z, Ning J C. 1994. Study on pollen morphology of plants from arid and semiarid areas in China. Yushania, 11: 119-191. (in Chinese)

Xu Q H, Tian F, Li Y C, et al. 2009. Pollen assemblages of Tauber traps and surface soil samples in steppe area of northern China and their relationship with vegetation and climate. Journal of Palaeography, 11(1): 81-90. (in Chinese)

Xu Y Q, Yan S, Jia B Q. 1996. Numerical relationship between the surface spore-pollen and surrounding vegetation on the southern slope of Tianshan Mountains. Arid Land Geography, 19: 24-30. (in Chinese)

Yan S, Xu Y Q. 1988. Pollen assemblages and environment change of plain area at the northern foot of Tianshan Mountain since Late Tertiary to Pleistocene. Xinjiang Geology, 6: 59-65. (in Chinese)

Yan S, Xu Y Q, 1989. Spore-pollen association in surface-soil in Altay, Xinjiang. Arid Zone Research, 1: 26-33. (in Chinese)

Yan S. 1993. The discussion on the pollen of family Pinaceae in surface soils in Xinjiang. Arid Land Geography, 16: 1-9. (in Chinese)

Yan S, Kong Z C, Yang Z J, et al. 2004. Relationships between spruce (Picea spp.) pollen of surface soils and vegetation in Xinjiang, northwestern China. Acta Ecologica Sinica. 24: 2017-2023. (in Chinese)

Yang Z J, Xu Q H, Meng L Y, et al. 2003. Quantitative relationship between pollen in the surface soil and vegetation in the Yanshan Area. Acta Phytoecologica Sinica, 27: 804-809. (in Chinese)

Yang Z J. 2004. A study on modern palynology in the north slope of mid-Tianshan Mt., Xinjiang. PhD Dissertation. Beijing: Institute of Botany, Chinese Academy of Sciences, 56-91. (in Chinese)

Yang Z J, Zhang Y, Bi Z W, et al. 2011. Surface pollen distribution in the southern slope of Tianshan Mountains, Xinjiang. Arid Land Geography, 34(6): 880-889. (in Chinese)

Yao Z J. 1993. A study on R-value of the relationship between pollen and vegetation. In: Li W Y, Yao Z J. Late Quaternary Vegetation and Environment of North and Middle Subtropical Region of China. Beijing: China Ocean Press, 97-103.

Yu G, Tang L Y, Yang X D, et al. 2001. Modern pollen samples from alpine vegetation on the Tibetan Plateau. Global Ecology and Biogeography, 10: 503-520. (in Chinese)

Zhang Y, Kong Z C, Wang G H, et al. 2010. Anthropogenic and climatic impacts on surface pollen assemblages along a precipitation gradient in northeastern China. Global Ecology and Biogeography, 19(5): 621-631.

Zhang H, Zhang Y, Kong Z C, et al. 2015. Late Holocene climate change and anthropogenic activities in north Xinjiang: Evidence from a peatland archive, the Caotanhu wetland. Holocene, 25: 323-332.

Zhao Y, Xu Q H, Huang X Z, et al. 2009. Differences of modern pollen assemblages from lake sediments and surface soils in arid and semi-arid China and their significance for pollen-based quantitative climate reconstruction. Review of Palaeobotany and Palynology, 156(3-4): 519-524.

Zhou X. 1995. Vertical climatic difference in the middle part of northern slope of Tianshan Mountains. Arid Land Geography, 18: 52-60. (in Chinese) 